\title{
Convocation Address - V
}

\section{N B Ratnasiri}

(Emeritus Professor, 28 November 2005)

Today is yet another day of celebration for the Open University of Sri Lanka. We assembled here to be a part of and celebrate the eighteenth convocation. Today, University confers degrees on the members of the graduating group of 2005. This is acknowledgement of their achievements,

1 congratulate all of you who are graduating today, and wish you a bright future. Your accomplishment, no doubt, is a result of your determination, dedication and hard work. On this day of celebration, let us also remember with gratitude the part played and sacrifices made by your loved ones, your family, friends and colleagues and of course your teachers. They would all have contributed enormously towards your achievement

For many years I have had the privilege of being part of the team that facilitated your learning at the University. Today, I am proud to be one amongst you and take my place as one receiving a degree from the Open University of Sri Lanka.

Chancellor, Vice Chancellor and Colleagues, it is an honour and pleasure to be here with you today. It is with a deep sense of privilege and humility that I say thank you for awarding me the highest degree of this University. 1 am deeply touched by the honour you have bestowed on me.

Those of you, who are graduating today, begin a new phase in your life. As you step into the world, it would be appropriate to reflect over how education has changed you. I believe you would have developed your inherent talents and skills, an attitude of rationalism along with creativity and imagination and the fundamental values sought after by society. If so, you would have received a good education which has developed in each one values, knowledge, rational thinking and of course adaptability. Your education then would have equipped you 
with the wherewithal for a productive and harmonious life, and enabled you to be a change agent for the betterment of society.

Having asked you to reflect on your education, let me share with you how education has helped me to face challenges, make decisions and adapt to new situations in life. My education, as is the case with every child, commenced with my parents. They instilled in me a strong sense of intellectual training and moral values. Thereafter, my education continued through school, universities and of course life.

The early days of my education were happy times with plenty of time to learn and plenty of time for sports. This gave me the opportunity to enjoy the company of my fellow students and make a wide circle of friends. I believe that it was this period of my life that laid the foundation for me to be a team player and develop the confidence, to one day attempt to contribute in my own small way for the betterment of society. The backdrop to all these activities was my home with plenty of love from my parents, grandparents, brothers and sisters, and my school with kind and understanding teachers and friendly fellow students.

The period of secondary and tertiary education was a time during which knowledge acquisition became a dominant component. My teachers ensured that I develop abilities of rational thinking, good values and adaptability. I thank my teachers for their guidance.

Equipped with a degree from the university, I stepped out into a world full of opportunities and promise. You may think that this was a very different situation to what you face today. I do agree that there are differences, but I must say that both opportunity and promise is before you in large measure if you have the courage and the confidence to face a different and changing world. Remember that no one can escape change; the secret of success is adaptability.

Learning to make the right decisions in life was my next challenge. Offered the option of several employment opportunities and also postgraduate study abroad, I decided to take up employment and leave postgraduate study for a later date. This was only because I did not have the courage to be away from my family and country at that time. $1 \mathrm{am}$ not certain whether I made the right decision. I believe I did. 
I accepted employment as a researcher in agricultural entomology, a field that I knew little to begin with. I became both a student and a researcher. It was one of the most enjoyable and rewarding periods of my life. 1 say this because being able to add to knowledge which would in some measure contribute to increased production of rice, the staple diet of billions of people, was extremely satisfying. During this period, I spent a considerable part of my time in the green paddy fields, with researchers, farmers, plants and animals in an environment very dear to me.

After a few years of employment, I developed the courage to be away from home and the country, and once again, it was decision time. I decided to embark on postgraduate study overseas. This was another very challenging and happy period in my life. On my return to the country and having worked for some time in agriculture, it was again a decision making time. This time, I opted to be a researcher in the forests instead of in the paddy fields. It was a difficult decision indeed, but circumstances prompted me to take that decision. With this change, I had to adapt to a whole new situation where I was the first woman forest researcher in the country.

The next decision in my life, made mid-way in my career resulted in venturing into a field I again knew little about. That was distance education. The Open University of Sri Lanka gave me this opportunity to be one of its team that was entrusted with the task of developing distance education in science at university level.

I joined the Open University 22 years ago, as the foundation Professor of Zoology. It was a great opportunity to join a team of pioneering Professors like the late Prof. Godwin Roberts, Prof. H. Sriyananda and Prof. Elsie Kotalawela and other young and dedicated staff. Prof. E M Jayasinghe, Prof. J N O Fernando and Prof. Joyce Paulraj who joined the science team soon after me, were all enthusiastic to ensure that the graduates of the Open University achieved the academic standards of excellence associated with the best of the conventional universities. Prof. Uma Coomaraswamy joined the team later.

The development of a distance education programme leading to a Bachelor's Degree in science was indeed a daunting task. No university anywhere in the world by then had developed such a programme. As the founder Dean of Science, it was my task to lead a very resourceful team of young staff. The dedication and the commitment of these determined young Professors and an equally determined even younger team of academics, support staff and administrators made my task 
easy and enjoyable. You, the graduates of today are proof of the untiring efforts of that team. I recognize and appreciate the valuable contributions made by these team members and others associated with this pioneering effort.

The environment of the university was perfect for new intellectual pursuits, which was in a big way due to the dedication and commitment of Prof. Dayantha Wijesekera, the then Vice Chancellor.

As I recall all meetings of the Departments, Faculties, Senate and Council, were places where issues and new ideas were debated and consensus reached, with only one purpose in mind, and that was academic excellence. It is a pleasure to think back of my fellow professors and colleagues and those days of discussions, disagreements, violent debates and finally consensus; all for the good of the students and the university. In spite of the strong disagreements and debates, which were all about issues, we have had over the years, it is with a feeling of sincere appreciation that I often think of my colleagues -Vice Chancellors, Deans, Professors, other teaching staff, administrative staff and the support staff - who have remained my friends. I am sure they will continue to be my friends for life.

I have shared with you some of my experiences in life with the hope that they will help you in some way to make the right decisions and adapt to face new situations with courage and determination.

Today, we live in a rapidly changing world. We are witnessing changes in the natural environment, development of new and advanced technologies and growth of knowledge, all driven by human aspirations. All these changes have economic, social, political and cultural implications.

There are many ways in which we have to be prepared to face these changes. We have to be able to change and adapt to new situations. We must also become change agents for the good of our society, our country and of course the world. This is an exorbitant demand. However, there is no alternative. How do we meet this demand? In my opinion, the answer lies in the education one receives, which will empower him with the necessary knowledge and skills and moral values to meet this challenge. 
Education provides for the development of character and plays a key role in this process. I believe that your objectives in seeking higher education would have been what I have just referred to. Let us think for a, while. Have you achieved your objectives? Have you had the intellectual and moral training leading to development of your character? Have you acquired the necessary knowledge and skills? In other words, are you prepared to face the changes that you will confront in life in a confident and just manner and can you change things for the better?

If you can answer these questions in the affirmative, we at the University can be satisfied that we have performed our duty and discharged our responsibility towards you as well as society. If you hesitate to answer, then it is necessary to take a good look at ourselves to see what changes have to be effected to achieve what I referred to earlier.

My experiences lead me to believe that our facilitation is more in the area of acquisition of knowledge and skills, which prepares students for both the local and overseas job markets. This is essential in the globalised world we live in today. I am in complete agreement that educational systems must provide students with the necessary knowledge and skills for them to be part of the global knowledge economy. In this backdrop, educational institutions are no doubt expected to produce graduates with the right knowledge and skills for cross border job markets, particularly when such opportunities are limited within the country. As you will agree, education has come to lay more emphasis on knowledge and skills rather than the development of the mind.

Our educational systems must develop an appreciation in our students about the good principles and standards of the values embedded in our cultures. No amount of knowledge and skills can make you a complete and contended person, if you have no appreciation and the right understanding about one's environment and society. If your education has equipped you with this appreciation and understanding, I believe you will be a contended and happy person in life. You will then be a part of the harmonious system that life should be for all of us. In such a situation, conflicts will be a thing of the past and peace and love which we all desire will be the order of the day.

All educational institutions and in particular the universities must facilitate the opening up of minds of those who have the good fortune to benefit from them. The Open University creates in my mind a picture 
of a university which removes barriers for access to knowledge and development of values for persons who have been denied this opportunity. The Open University of Sri Lanka has to a considerable extent made university education a reality for all who seek it. Therefore, I consider the founders of this University to be visionaries who have responded to the needs of the country in many different ways.

The open admission policy of the Open University is very far sighted. The challenge that has always faced those who want to expand education is to achieve a balance among three tasks - making education accessible to as many as possible; ensuring quality of education and achieving these at an affordable cost. The basic constraints of these challenges have had a negative influence on the development of education throughout history. If we look at the world, entry to institutions that provide education through conventional faceto-face teaching have resorted to many ways that restrict entry establishing exclusivity.

The open admission policy has played a major role among other things to make university education in the country accessible to those for whom conventional universities are out of reach for whatever reason, and thereby has achieved the first objective. I cannot emphasize enough the huge influence open and distance education has had on the removal of barriers to university education in our country.

We are a developing country with limited resources. It is therefore necessary that we provide access to quality education at a reasonable and affordable cost. Open and distance learning is the answer to this problem. However, open and distance learning is linked inextricably with technology, which applies, scientific and other organized knowledge to practical tasks using machines. Today, new technologies such as Information and Communication Technologies or ICTs have wielded a huge influence on quality open and distance learning. Elearning is steadily gaining in importance towards the effort of making quality education for all a reality.

While agreeing whole heartedly that open and distance learning is definitely the answer to the problem of access to quality higher education, I must share with you two concerns that have lingered in my mind for a long period of time. If we depend too much on highly advanced technology, will we be once again faced with the problem of 
making the system less accessible to the masses and also enhancing the costs? In my opinion, we in developing countries with our limited resources at present, have a grave responsibility to bear this in mind.

My second concern with regard to open and distance learning with its extensive emphasis on educational technology is that while it is a significant supplement, it cannot replace the human element and the role of the quality teacher. The good teacher facilitates the acquisition of knowledge and skills, and intellectual and moral training to provide for the development of character. At this stage, I bow my head to all such teachers here at the Open University, who have strived to impart the all important human touch.

The new graduates of today must keep in mind that your qualification is not the end of learning. It gives you access to further learning. You will be a winner in life if you continue to learn and give a helping hand to those who are less fortunate than you.

I wish to conclude leaving you to think about what the great Indian Poet Rabindranath Tagore has said that "the object of education is to give man the unity of truth". 